\title{
Edebiyat Teorisi: Rabelais ve Dünyası YASEMIN KOÇ*
}

\section{7 abelais ve Dünyası ${ }^{* *}$ isimli çeviri kitap, 2005 yılında Ayrıntı Yayınları tarafindan basılmıştır.} Bahtin'in İngilizceye çevrilen ilk kitabı Rabelaisand His World (Rabelais ve Dünyası) 1968 yılında yayımlanır. Bu kitap basıldı̆̆ında Mihail Bahtin Batı'da henüz tanınmıyordu. Ancak bugün Mihail Bahtin edebiyat alanında ve beşeri bilimlerde uluslararası bir ünün sahibidir.

Edebiyat incelemesi ve eleştirisi açısından büyük önem arz eden bu kitabı tanıtabilmek için öncelikle kitabın yazarı Mihail Bahtin ve eserleri ile Fançois Rabelais hakkında kısa bir bilgi vereceğiz. Daha sonra kitabı tanitıp değerlendireceğiz.

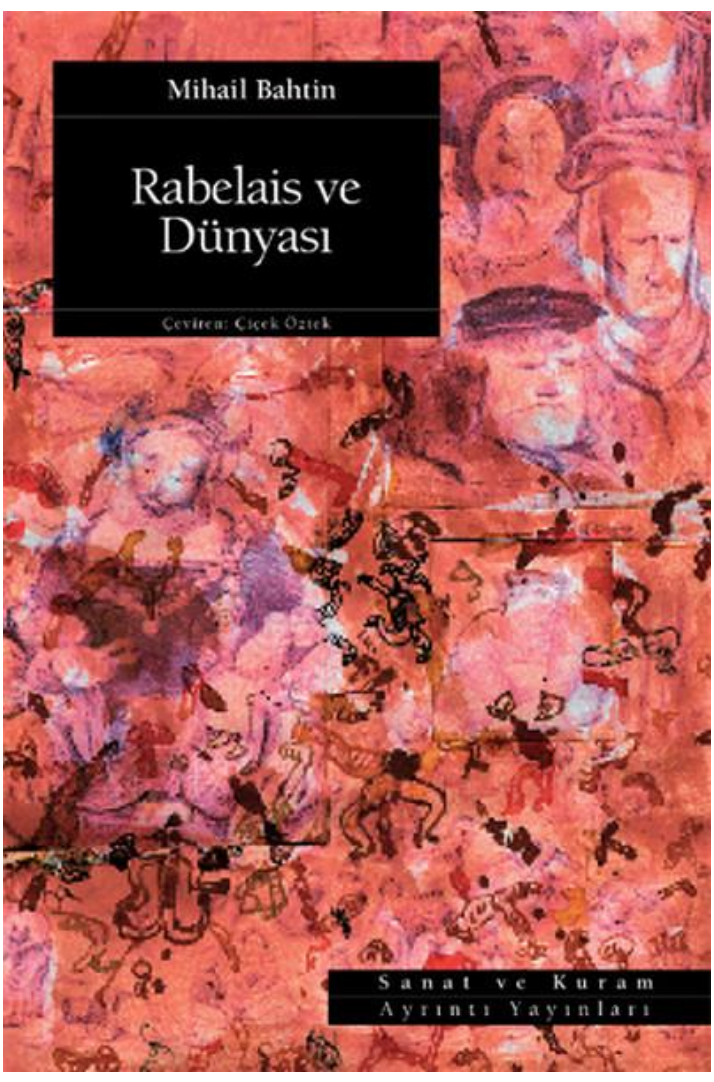

\section{Mihail Mihailovic Bahtin (1895-1975)}

Mihail Bahtin 16 Kasım 1895 tarihinde Moskova'nın güneyinde yer alan Orel kentinde dünyaya gelmiştir. Babasının bir banka görevlisi olduğu söylenir. Lise eğitimini Odessa'da tamamlar. 1913 yılında yerel üniversitenin tarih ve filoloji fakültesine kaydolur. Kısa bir süre sonra abisi Nikolay'ın eğitim aldığı Petersburg Üniversitesine geçiş yapar. Ancak Bahtin’in üniversiteyi bitirip bitirmediği bilinmemektedir.

Mihail Bahtin'in Dostoyevski Poetikasının Sorunları adlı eseri 1929 yılında yayımlanır. Bu eser yayımlandıktan sonra Bahtin tutuklanır. 1938'de sağlık sorunları nedeniyle cezası sürgüne çevrilir. Mihail Bahtin Kazakistan’a sürgün edilir. 1938 yılında kemik hastalığına yakalanır. Bir bacağı kesilir.

Mihail Bahtin Sovyet rejimiyle yaşadı̆̆ı problemlerden dolayı maddi sıkıntılarla boğuşmak zorunda kalmıştır. Bir anekdota göre II. Dünya Savaşı'nın yokluk ve kıtlık

\footnotetext{
*Adnan Menderes Üniversitesi Sosyal Bilimler Enstitüsü doktora öğrencisi, yaseminkoc07@gmail.com

** Mihail Bahtin, Rabelais ve Dünyası, Çev. Çiçek Öztek, Ayrıntı Yayınları, İstanbul 2005.
} 


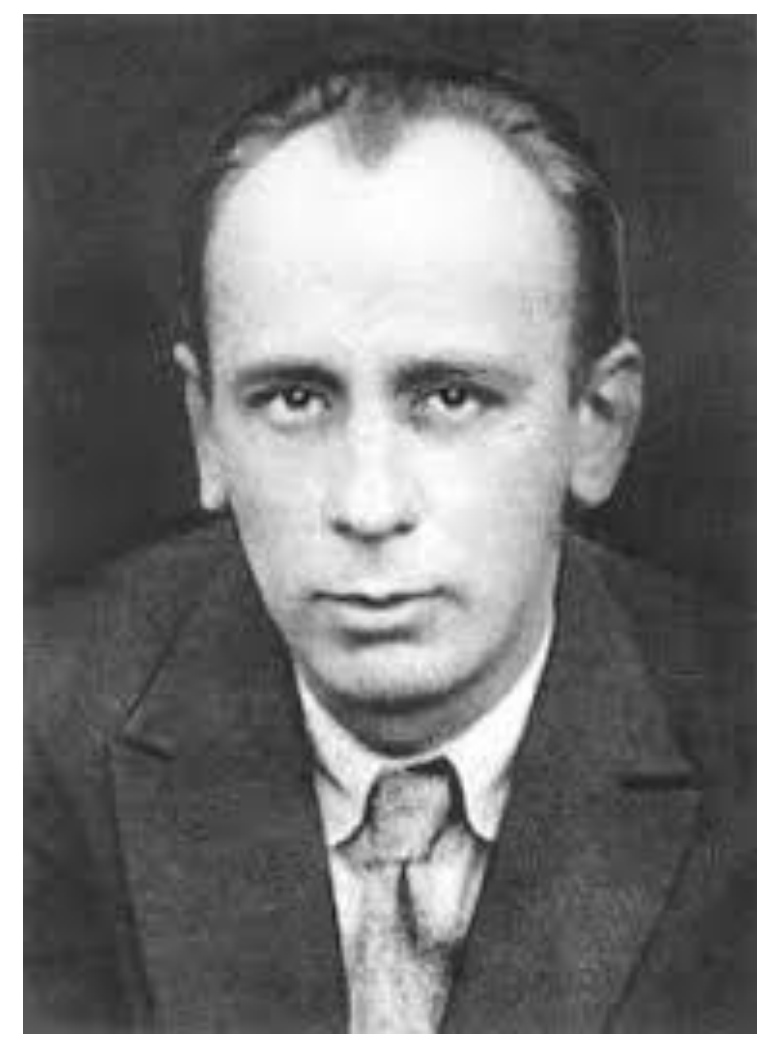

Mihail Bahtin

yıllarında 18.yüzyıl Alman roman türü üzerine yaptığı çalışmanın kâğıtlarını tütününü sarmak için kullanmıştır.

Bahtin, Rabelais ve Dünyası adlı notlarını 1940 yllında tek bir metin haline getirir. Moskova'da kurulan Gorki Dünya Edebiyatı Enstitüsü'ne tezini sunmak için başvurur. Ancak II. Dünya Savaşı'nın patlak vermesi nedeniyle tez savunması ertelenir. Mihail Bahtin, tezini savunması için Moskova'ya 1947 yılında davet edilir. Tezinin Batılı bir yazar üzerine olması ve de biçimci bir gelenekten gelmesi onun aleyhine bir imaj yaratır. Ancak Bahtin tezini retorik bir maharetle sunarak jüri üyelerini etkiler. Ona doktor unvanı vermeyi düşünürler. Ancak muhafazakâr jüri üyeleri buna engel olur.

1960’ların başında Gorki Enstitüsü öğrencilerinden bir grup genç akademisyen Mihail Bahtin'i keşfeder. Bahtin'in Rabelaisve Dünyası adlı tezinin kitap olarak basılması için çalışmalara başlarlar. Ancak Bahtin'in arkadaşları öncesinde ilk yayımı 1929'da yapılan Dostoyevski Poetikasının Sorunları adlı eserinin yayımlanmasının daha kolay olacağını düşünürler. Bu nedenle 1963'te kitabın ikinci baskısı yapılır. 1965'te de Rabelais ve Dünyası adlı doktora tezi basılır.

Mihail Bahtin, Sovyet edebiyat eleştirmeni ve kuramcısı olarak önemli bir yere sahiptir. Dönemin siyasi baskısı onun zorlu bir hayat mücadelesi vermesine neden olduğu için ilmi çalışmaları sekteye uğramıştır.

Bahtin 1969'da Moskova'ya yerleşir. 1975'te yaşlılar evinde ölür. Eserleri: Dosteyevski Poetikasının Sorunları 1929, Rabelais ve Dünyası 1965, Romanın Estetiŏi ve Kuramı 1978, Sözsel Sanatın Estetiği 1979, Diyolojik Söylem 1981.

\section{François Rabelais}

1492 yılında bazı kaynaklara göre ise 1483/1489 yılında Touraine bölgesinde Chinon yakınlarında La Deviniere olarak bilinen topraklarda dünyaya gelmiştir. Rabelais, dokuz-on yaşlarında Seuilly'de yer alan bir manastıra gönderilir. Manastırda tanıdığı Buinart adındaki genç bir keşişten etkilenir. Kaleme aldığı eserlerinde bu keşiş Papaz Jean adıyla yer alır. 
Rabelais, Seuilly Manastırı'nda almış olduğu eğitimden sonra çeşitli manastırlara gider. 1520 yılında Fontenay-Le-Comte Manastırı'na keşiş olarak gider. Dinî kariyeri esnasında pek çok okuma yapar. Bir süre sonra manastırın katı disiplinine dayanamaz. 1528'de dinî kurallar çerçevesinde yaşamaktan vazgeçer. Paris'e tıp eğitimi almaya gider. Yaşam şeklini değiştirmesi sebebiyle kilise tarafından dinden dönmekle suçlanır.

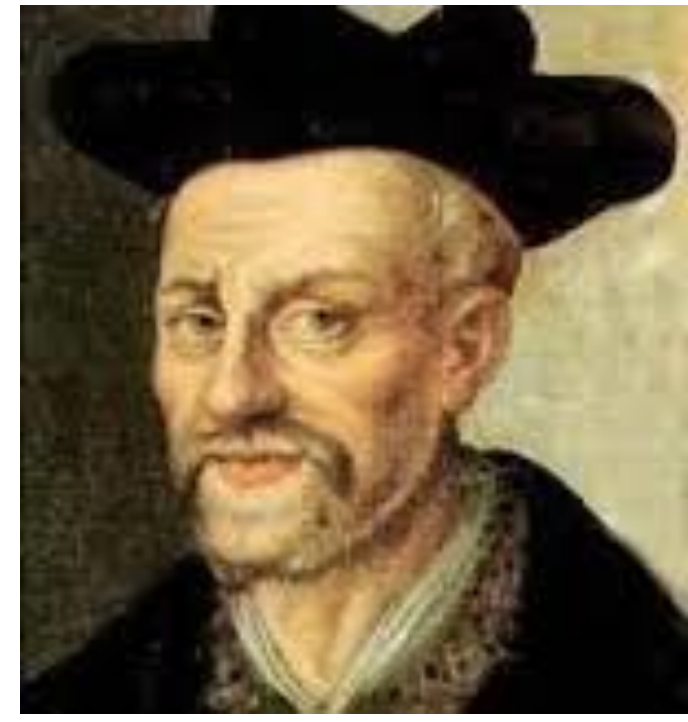

Rabelais

Paris'te yaşadı̆̆ı bu süre zarfında dul bir kadınla evlilik dışı bir ilişki yaşar. Bu birliktelikten iki çocuğu olur.17 Eylül 1530 tarihinde Hipokrat ve Galien üzerine ders vermek için Montpellier Tıp Akademisi'ne girer. Sonraki dönemde Lyon'a yerleşir. Tıp doktoru olarak kariyer yapar.

Rabelais'nin ilk eseri Pantagruel'i Alcofribas Nasier takma adı ile 1534 yılında yayımlanır. Bu kitabın başarılı olması üzerine 1534 yılında ikinci kitabı Gargantua'yı aynı takma adla kaleme alır. Kitapları Sorbonne tarafından mahkûm edildiği için takma ismi önlem olarak kullanır. Aynı yıl Lyon'da hem epik hem de komik halk masallarından derlediği Koca Dev Gargantua'nın Büyük ve Malum Vakayinamesi adlı kitabı yayımlanır.

Bir süre sonra kardinal olarak atanan Jean du Bellay, Rabelais'nin Papa tarafindan affedilmesini sağlar. 1536 yılında manastıra dönme ve doktorluk mesleğini yapma hakkı elde eder. 1540 yılında evlilik dışı dünyaya gelen çocukları François ve Junie III. Paul tarafından kiliseye kabul edilir.

1545 yılında Üçüncü Kitap'ın basımı için kraliyet izni alır.1546 yılında kitabın ilk baskısı yapılır. Kitabı ilk kez kendi adıyla imzalar. Ancak kitap sapkınlık nedeni ile sansür edilir. Rabelais bu olaydan sonra 1946'da Metz'de doktorluk yapmaya başlar. Burada Dördüncü Kitap'1 yazar. Kitap 1552'de yayımlanır. Kardinal du Bellay, Rabelais'yi Saint Martin de Meudon ve Saint Christophe-duJambet papazlı̆̆ına18 Ocak 1551 tarihinde atar. Rabelais 1553'te tıp doktorluğunu bırakır. Ölüm tarihi ve yeri tam olarak bilinmemektedir.1553 yılında Paris'te öldügü söylenir. 1564 yılında Beşinci Kitap'ın tam metni yayımlanır.François Rabelais baba-oğul iki dev olan Gargantua ve Pantagruel'in hayatını beş ciltlik eseriyle anlatır. Rabelais, Fransız ve dünya edebiyatında önemli bir yere sahiptir. 


\section{Rabelais ve Dünyası'nda Ele Alınan Konular}

Rabelais ve Dünyası adlı eser Kristina Pomorska'nın önsöz yazıyla başlar. Ardından Michael Holquist'in İngilizce baskıya önsöz adlı bir yazısı ile devam eder. Giriş yazısı ile kitap başlar. Eser yedi ana bölümden oluşmaktadır. Gülmenin Tarihinde Rabelais, Rabelais'de Pazar Meydan Dili, Rabelais'de Popüler Şenlikli Biçim ve İmgeler, Rabelais'de Şölen İmge Dokusu, Bedenin Grotesk İmgesi ve Bunun Kökenleri, Maddi Bedensel Bölgelere Ait İmgeler ve Rabelais'nin İmgeleri adlı bölümlerden oluşmaktadır.

Mihail Bahtin Rabelais ve Dünyası adlı yapitında Rönesans döneminin önemli yazarlarından biri olan François Rabelais'nin eserlerinde Ortaçağ ve Rönesans halk mizahının köklerinin izlerini sürer. Rabelais ve Dünyası adlı yazınbilim incelemesinde karnaval, gülme ve grotesk gerçeklik öne çıkan kavramlardır.

Giriş kısmında François Rabelais'nin dünya edebiyatında en az anlaşılan ve takdir edilen yazar olduğunu dile getirir. Edebi başarısı ve tarihsel önemi dolayısıyla Batı edebiyatı eleştirmen ve yazarlarının onu Shakespeare'den sonra andıklarını dile getirir. Rabelais'nin tarihteki yerinin modern Avrupa edebiyatının önemli temsilcileri olan Dante, Boccaccio, Shakespeare ve Cervantes'in yanı olduğunu ifade eder.

Bahtin'e göre Shakespeare ve Cervantes'in özünü anlayamayan Romantikler Rabelais'yi de anlamamıştır. Rabelais'nin eserleri halk mizah kültürünün hazinesini açan anahtar mahiyetindedir.

Halk mizah kültürünün tezahürlerinin üç biçime ayırır. Bunların birbirine sıkı sıkıya bağlı olduğunu dile getirir:

1. Ritüel Gösteriler: Karnaval geçitleri, Pazar meydanında yapılan komik temaşalar

2. Komik Sözlü Terkipler: Sözlü ve yazılı hem Latince hem de gündelik dilde parodiler

3. Çeşitli edepsiz türler: Beddualar, küfürler, popüler blazonlar

Karnavalların yanı sıra Deliler bayramı, Eşek bayramı, Paskalya Gülüşü ve Hasat mevsimlerinde yapılan eğlencelerin de Ortaçağ insanın hayatında önemli bir yeri vardır. Panayırların kurulduğu açı hava eğlencelerinin müdavimleri devler, cüceler, hilkat garibeleri ve eğitimli hayvanlardır.

Gülmeye dayanan ve geleneğin kabul ettiği ritüellerin Ortaçağ Avrupası'nın bütün ülkelerinde mevcut olduğunu ifade eder. Karnaval gülüşü kilisenin dinsel dogmatizminin tekelinden çıkartılır.

Karnaval insanlar tarafından seyredilen bir gösteri değildir; insanlar onun içinde yaşarlar, herkes ona katılır, karnaval bütün insanları kucaklar (Bahtin, 2005: 33-34).

Bayramların kültür tarihinde önemli bir yeri ve felsefi bir derinliği olduğunu ifade eder. Ortaçağ'ın resmi bayramlarının kiliseye ve feodal düzene tabi olduklarını ve devlet 
tarafından desteklendiğini belirtir. Karnavalın ise egemen anlayıştan özgür olduğunu vurgular:

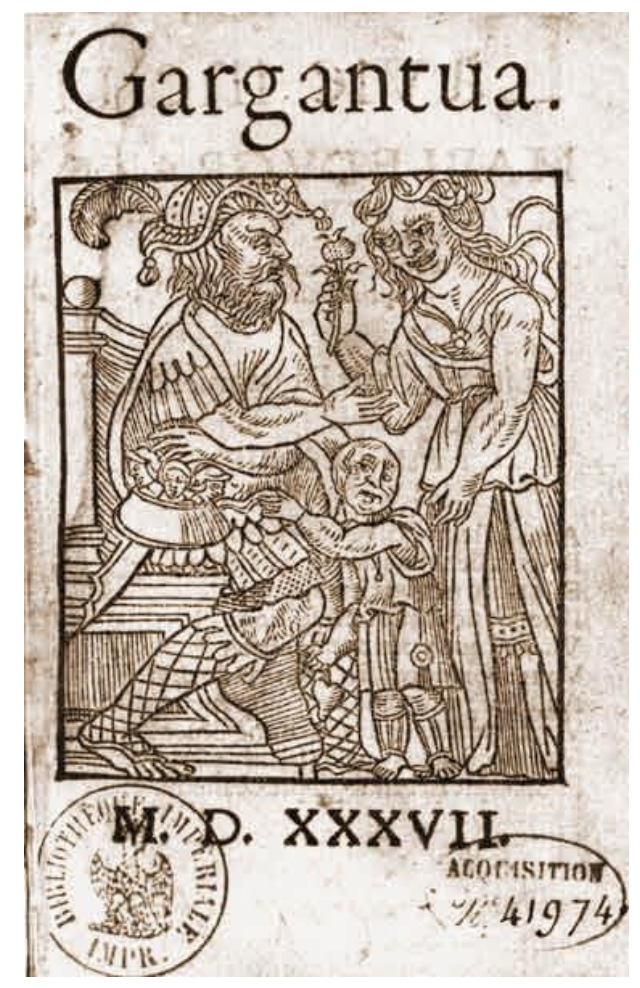

Karnaval zamanı tüm hiyerarşik önceliklerin askıya alınmasının özel bir önemi vardı. Resmi bayramlarda rütbe özellikle öne çıkan bir şeydi; bu bayramlarda herkesten sinifina, rütbesine ve niteliklerine göre tamamen belli kurallar içinde hareket etmeleri beklenirdi, herkesin yeri belliydi. $\mathrm{Bu}$ bayramlar eşitsizliğin takdis edilmesiydi. Hâlbuki karnavalda her şey birbirine eşit kabul edilirdi. Normalde kast, mülkiyet, meslek, yaş bariyerleriyle birbirinden ayrılan insanlar arasında karnaval zamanı bu etkinliğe has özgür ve dostane bir ilişki biçimi egemen olurdu (Bahtin, 2005: 26).

Ortaçağ toplumsal düzeninde çok katı hiyerarşik bir yapı vardır. Bu nedenle yaşanan bu özgürlüğün karnaval âleminde önemi büyüktür. Halk kültürünün ikinci dünyasında bir ters yüz olma hali vardır. Taç giydirme, tacı geri alma törenleri törenin önemli etkinlikleridir.

Mihail Bahtin kitabı yazma amacından bahseder: Bu kitabın temel amacı, yarı yarıya unutulmuş pek çok açıdan karanlıkta kalan bu dili anlamaktır. Zira Rabelais tarafından kullanılan dil, tamı tamına bu dildir ve onu anlamaksızın Rabelais'nin imgeler sistemini anlamamız mümkün değildir (Bahtin, 2005: 38).

Bahtin karnaval gülüşünün halkın gülüşü olduğunu, evrensel olduğunu ve müphem olduğunu vurgular. Müphemdir yani hem neşe ve zafer dolu hem de alaycı ve taklitçidir. Günümüzün gülme algısının felsefi anlamından uzaklaştırıldığını ifade eder. Gülmenin yalnızca eğlenceli ve neşeli boyutuyla ele alındığını dile getirir.

Pazar meydanlarında teklifsiz konuşmalar tipik bir özellik gösterir: Pazar meydanında yapılan teklifsiz konuşmaların tipik bir özelliği, sövgüsel bir dil, hakaret dolu söz ve ifade kullanımlarıdır; bunların bazıları oldukça uzun ve karmaşıktır. Sövgü gramatik ve semantik bağlamdan koparılırdı; bu kendi içinde bütünsel bir birim, atasözüne benzer bir şey olarak görülürdü. [...] Bu sövgüler müphemdi. Bir yandan hakaret edip küçük düşürürken bir yandan da hayat ve tazelik verirlerdi.(Bahtin, 2005: 43-44)

Rabelais'nin eserlerinde maddi bedensellik ilkesi önemli bir yere sahiptir. Maddi bedensellik ilkesi bedenin yeme- içme, dişkılama ve cinsel hayata ait imgelerini içerir. Maddi bedensellik ilkesinin halk mizah kültürünün önemli bir mirası olduğunu ifade eder. 
Victor Hugo, Rabelais'yi etin ve belden aşağısının şairlerinin en büyüğü olarak görür. Genel eleştiriler ise abartılı bir fizyolojizm, biyolojizm ya da natüralizm üzerinedir. Benzer özelliklerin Rönesans edebiyatının önemli temsilcileri olan Boccaccio, Shakespeare ve Cervantes'te de var olduğunu savunur.

Grotesk gerçekçilikte bedensel unsur son derece olumludur. $\mathrm{Bu}$, hayatın diğer alanlarından kopuk, mahrem ve hodbince değil tüm halkı temsil eden evrensel bir şey olarak sunulur. Kaba saba olan şeylerle alakası yokmuş numarası yapmaz ya da dünya ile bedenin bağımsız iki şey olduğunu iddia etmez (Bahtin, 2005: 46).

Maddi bedensellik ilkesinin bireyde ve burjuva egosunda değil halkta olduğunun altını çizer. Maddi bedensellik ilkesinin en önemli imgelerinin doğurganlık, büyüme ve bolluk olduğunu ifade eder. Grotesk gerçekçiliğinin temel ilkesi itibarsızlaştırmak, yani yüksek ruhani, ideal, soyut olan her şeyi yukarıdan aşağıya indirmektir; yukarıdakileri maddi düzeye, dünya ve bedenin alanlarına aktarmaktır (Bahtin, 2005: 47).

Maddi bedensellik ilkesinde yukarı ve aşağının topografik anlamı vurgulanır. Yukarı semayı, yüz ve kafayı; aşağı dünyayı, üreme organlarını, karın ve kaba etleri temsil eder.

İtibarsızlaştırmanın Rönesans edebiyatının tipik bir özelliği olduğunu; ancak evrensel ve şenlik ruhunun zayıfladığını ifade eder. Bunun tipik örneğinin de Don Quijote olduğunu söyler. Grotesk imgenin dönüşüm halinde olan bir fenomeni yansıttı̆̆ını dile getirir. Grotesk gerçekçiliğin arkaik dönemlerinde zaman mefhumunun eş zamanlı olarak verildiğini dile getirir. Başlangıç-son, kış-bahar, doğum-ölüm gibi... Bu imgeler insanın ve doğanın üreme hayatını temsil eder. Ancak zaman mefhumu algısı değişime uğrar. Toplumsal ve tarihsel zaman algisı da devreye girer.

Bahtin grotesk beden algısının modern anlayıştan farklı olduğunu ifade eder: Modern kanonlardaki bedenlerin aksine grotesk beden dünyanın geri kalanından ayrılmaz. $\mathrm{O}$ ucu kapanmış, tamamlanmış bir birim değildir; o henüz bitmemiş bir şeydir, kendine büyük gelir, kendi sınırlarını ihlal eder. Vurgu bedenin dış dünyaya açılan, dış dünyanın bedene girdiği ve oradan yine dışarı fışkırdığı kısımlarındadır; yani bedenin dış dünyaya açılan, dış dünyanın bedene girdiği ve oradan yine fışkırdığı kısımlarınadır; yani bedenin dışarıyla bağlantı kuran yerleriyle. Başka bir deyişle deliklerin veya tümseklerin ya da dallanıp budaklanan çeşitli uzantıların altı çizilir. Açıkağız, üreme organları göğüsler, penis, göbek, burun (Bahtin, 2005: 53).

Grotesk imge dokusunun mitolojide ve arkaik sanatlarda var olduğunu ifade eder. Grotesk imge terimi ilk kez XV. yüzyılın sonlarında bulunan bir Roma süslemesi için kullanılır. Bu süslemenin hayal, özgür ve oyun ruhunu barındırdığı söylenir. 
Klasik kanonun XVII. yüzyıl ve XVIII. yüzyılın ilk yarısının sanat ve edebiyatının tüm alanlarında sürdüğü egemenlik nedeniyle halk edebiyatının önemli bir yanını temsil eden grotesk edebiyattan dişlanır.

Bir yandan devlet şenlikli hayata tecavüz edip onu bir resmigeçide dönüştürmüştü; öte yandan bu şenlikler kapalı kapılar ardında yapılır olmuş, ailenin mahrem hayatının bir parçası haline gelmişti. Pazar meydanında tanınan ayrıcalıklar yavaş yavaş sınırlandırılmaktaydı. Bayram halkın ikinci hayatı, geçici yeniden doğuşu ve tazelenişleri olmaktan neredeyse tamamen çıkmıştı (Bahtin, 2005: 61). Ortaçağ ve Rönesans Grotesk'in aksine Romantik Grotesk salon özelliği kazanır. Bireysel bir karnavala dönüşür. Romantik Grotesk'te korku havası egemendir. Bu türün örneklerinde karanlık ve gece hâkimdir. Halk kültürü ise ışığı, aydınlığı temsil eder.

Romantik Grotesk'te gülme imgesi yeniden hayat veren özelliğini yitirir. Gülme imgesi artık soğuk ve iğneleyici alaya indirgenir. Halk Grotesk'inde delilik resmi anlayışın ve de dar kafalı zihniyetin parodisi iken Romantik Grotesk'te bireysel tecridin imgesidir. Halk Grotesk'inde maske imgesi değişim ve dirilişi sembolize eder. Bir örnekliği reddeder. Romantik Grotesk'te ise maske hayat veren ve tazeleyen özelliğini kaybetmiştir.

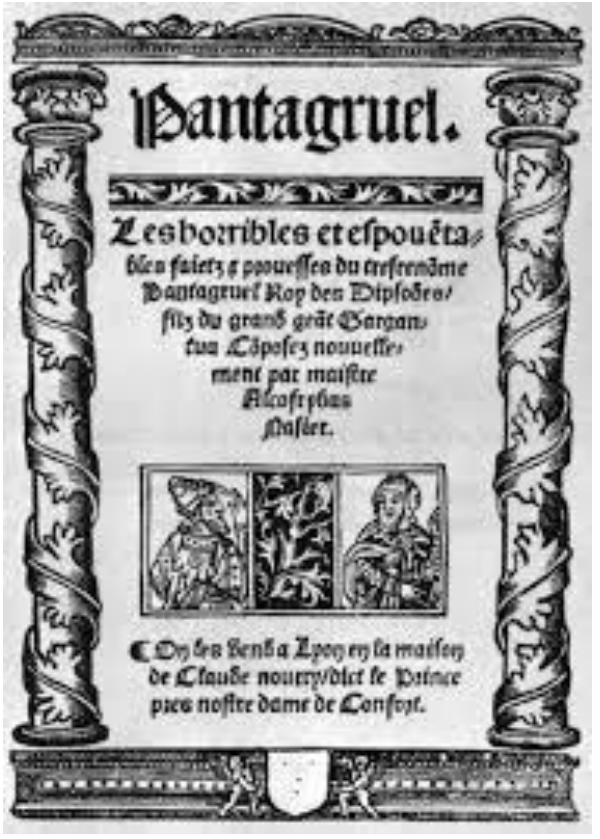
Kasvet veren bir ruha bürünmüştür. Romantik Grotesk'te kukla imgesi yabancı bir gücün insanlığı kuklalara çevirip hükmetmesini temsil eder. Romantik Grotesk'in şeytan imge algısı da halk kültüründen farklıdır. Halk Grotesk'inde şeytan gayr-i resmi anlayışı, maddi bedensel bölgeleri temsil etmektedir.

Bahtin, XX. yüzyıl Grotesk anlayışını analiz eder: Grotesk XX. yüzyılda güçlü bir şekilde yeniden canlandı. [...] Genel olarak söylersek iki ana gelişim hattı vardır. Bunlardan birincisi "modernist hattır" bu hat romantik gelenekle ilişkilidir ve varoluşçuluk etkisi altında evrimleşmiştir. İkinci hat ise "gerçekçi grotesktir" (Thomass Mann, Pablo Neruda ve diğerleri); bu hat gerçekçilik geleneği ve halk kültürüyle ilişkilidir, kimi zaman karnaval biçimlerinin doğrudan etkisini yansıtır ( Bahtin, 2005: 74).

Alman edebiyat eleştirmeni Wolfgang Kayser, grotesk hakkında bir kitap yayımlar. Bahtin, kitabın kuram hakkında yazılmış bir ilk eser olduğunu ifade eder. Ancak kitabı Romantik ve modernist kuram incelemelerinden ibaret olması nedeniyle eleştirir.

Rabelais'nin eserlerinin ortaçağ halk kültürü ile ilişkili olduğunu, Cervantes ve Shakespeare'de görülen Rönesans imge dokusunun gerçekçi edebiyata ilham verdiğini dile 
getirir. Stendhal, Balzac, Hugo, Dickens gibi gerçekçi edebiyatın temsilcilerinden de örnekler verir.

\section{Gülmenin Tarihinde Rabelais}

Rabelais'yi çağdaşlarının ve XVI. yüzyıl halkının sevdiğini; ancak hümanist çevrenin ve de yüksek burjuvazinin sevmediğini belirtir. Rabelais'nin çağdaşlarından tarihçi Etienne Pasquier yazdığı bir mektupta ondan bahseder: Aramızda Rabelais'nin Gargantua ve Pantagruel'de zekice komiklik yaparak halkın sevgisini ne kadar kazandığını bilmeyen yok (Bahtin, 2005: 87-88).

Rabelais'yi seven Montaigne denemelerinde ona atıfta bulunur: Sırf eğlendirici yapitlara gelince yeni kitaplar arasında Boccaccio'nun Decameron'u, Rabelais'yi bizi eğlendirmeye addediyorum (Bahtin, 2005: 93).

Montaigne'in eğlendirici ve neşeli söylemleri olumsuz boyutuyla algılanmamalıdır. Zira kastettiği düşük, seviyesiz ve yersiz anlamlarından azadedir. Rönesans'ın gülme anlayışının felsefi bir anlamı vardır. Gülmenin insanın hakikat biçimlerinden biri olduğunu ifade eder.

Hipokratik romanda gülme şifa verici gücü ile öne çıkar. Aristoteles ise gülmenin tüm varlıklar arasında yalnızca insana bahşedildiğini ve de insanın tinsel ayrıcalığı olduğunu ifade eder. Rabelais'nin Gargantua adlı eserinin giriş şiirinin son iki dizesi Aristoteles'in ifadelerinin yansımasıdır:

Gülen kitap yeğdir ă̆layan kitaptan

Gülmektir çünkü insanı insan eden

Rönesans gülmesinin son kaynağ1 ise Lukianos'un ölüler kralına gülen Menippos imgesidir. Menippos imgesi ölüler diyarına inişi temsil eder. Gülme, Ortaçă̆ resmi ideolojisinden dışlanmıştır.

Ortaçağ'da gülme, ideolojinin tüm resmi alanlarının ve toplumsal ilişkilerin tüm resmi, katı biçimlerinin dışında kalmıştı. Gülme dinsel kültten, feodal törenler ve devlet törenlerinden, adabı muaşeretten ve tüm yüksek spekülasyon türlerinden dişlanmıştı. Hoşgörüsüz tek yanlı bir ciddiyet havası, resmi Ortaçağ kültürünün tipik özelliğiydi. Ortaçağ ideolojisinin içerdikleri çilecilik, kasvetli kadercilik, günah, ceza, ıstırap baskıcılığı ve sindiriciliğiyle feodal rejimin karakteri ciddiyet havasını belirlemiştir. Bu ciddiyetin ögeleriyse korku, korkuyla karışık dinsel saygı ve alçakgönüllülüktü (Bahtin, 2005: 101).

Deliler Bayramı, Eşek Bayramı, Paskalya Gülüşü, Noel Gülmesi gülmenin baş tacı edildiği kutlama törenleridir. Bahtin, şenlik törenlerinin eğlencelerinden örnekler verir:

Elbiselerin tersyüz edilerek giyilmesi ve pantolonların başa geçirilmesinden, dalga geçilen sahte kralların ve papaların seçilmesine kadar aynı topografik mantık hüküm sürüyordu: yukardakini aşağı kaydırma, yüce ve eskiyi, son şeklini almış ve tamamlanmış 
olanı ölüm ve yeniden doğum için maddi bedensel alt bölgelere gönderme (Bahtin, 2005: 109). Bahtin, Fransiz Romantik'lerinden Chateaubriand'ın Rabelais'nin eserlerine yaklaşımını verir:

Chateaubriand bir ulusun tüm diğer büyük yazarlarını doğup yetiştiren "ana dehalardan" söz ettiğinde Romantiklerin tipik bir görüşünü ifade eder. Tüm dünyada yalnızca beş ya da altı ana deha vardır. Rabelais de Homeros, Shakespeare ve Dante ile birlikte bu dehalar arasında yer alır. Tipkı Homeros'un Yunan ve Roma edebiyatını, Shakspeare'in İngiliz edebiyatını ve Dante'nin İtalyan edebiyatını yaratması gibi Rabelais de Fransız edebiyatını yaratmıştır (Bahtin, 2005: 149).

Romantikler "ana fikir dehası" arayışı içerisinde olmuşlardır. Bu arayış da romantikleri geleceğin tohumlarını geçmişte aramaya sevk etmiştir. Romantiklerde zaman ve tarih mefhumu önemlidir. Bahtin, Victor Hugo'nun Rabelais'nin imgelerini doğru anladığını; ancak yanlış yorumladığını ifade eder:

Hugo, gülme, eski dünyanın ölümü, cehennem ve (oburca yiyen ve yutan) ziyafet imgeleri arasındaki ilişkiye doğru bir şekilde dikkat çekti, ama sonra bu bağlantıyı yanlış yorumladı. Bu bağlantıya ahlaki-felsefi bir nitelik kazandırmaya çalıştı. Bedenin alt bölgelerinin yeniden teşekkül ettirici ve yenileyici gücünü anlayamadı. Bu yanılg1 ise gözlemlerinin değerini azaltıyor (Bahtin, 2005: 152).

Mihail Bahtin devrim öncesi Rus edebiyatının François Rabelais'nin eserlerine kayıtsız kaldığını ifade eder. Çalışmaların ise A. N. Veselovski'ninRabelais ve Romanı adlı makalesi ve I. Focht'un risalesi ile sınırlı olduğunu söyler. Sovyet edebiyat eleştirisinin de II. Dünya Savaşı'na kadar mevcut durumunu değiştirmediğini vurgular. 1948 yılında E.M. Evnina'nın Rabelais üzerine ilk Sovyet monografisi yayımlanır. Bahtin, Sovyet incelemelerindeki en önemli olayın L.E.Pinski'nin Rönesans'ın Gerçekçiliği kitabında yer alan Rabelais'nin Gülmesi adlı denemesi olduğunu dile getirir.

\section{Rabelais'de Pazar Meydan Dili}

Bahtin, Rabelais'nin eserlerinde yer alan edepsiz konuşmaları değerlendirir: Rabelais'deki edepsiz konuşmalar, günümüzde bile, sadece ortalama halkın değil sadık okurlarının nezdinde dahi onu zor bir yazar kılar. Kaba saba kelimeleri romanın sanatsal dokusuna yedirmek güçtür. Modern zamanlarda bu tür terimlerin çoğunun aldiğı özel anlamlar, Rabelais'nin yazılarının doğru bir yorumunu güçleştirir; zamanında o terimler evrenseldi ve pornografiyle hiç alakası yoktu. (Bahtin, 2005: 172)

Dışkılamanın ritüellerde önemli bir rolü vardır. Rabelais'nin eserlerinde çişten boğulmak, çişten sırılsıklam olmak gibi söylemler sıkça karşımıza çıkar. Dışkı atmak, çişle 
1slatmak gibi jestlerin geleneksel alçaltma jestleri olduğunu, sadece grotesk gerçekçiliğin değil antikitenin de bildiği bir şey olduğunu belirtir.

IV. Kitap'ta Panurge'ün sürüsünün başından geçen olaylarda tüccar Dingdong koyunlarına övgüler yağdırır. Koyunlarının çişlerinin tıpkı tanrıların çişi gibi, dünyanın verimini arttıracak büyülü bir güce sahip olduğunu söyler. Bahtin, Rabelais'nin eserlerini modern yorum ruhuyla incelediklerini dile getirir. Bu nedenle imgelerin müphemliğinin anlaşılmadığını vurgular. Muhteşem Vakayiname'de Gargantua üç ay, yedi gün, on üç saat, kırk yedi dakika boyunca işer ve Rhone Nehri'ni ve yedi yüz gemiyi doğurur (Bahtin, 2005: 177).

Rabelais'in II. Kitap'ında Fransa ve İtalya'nın şifalı kaplıcalarının Pantagruel'inçişinden yaratıldığı söylenmektedir. Dışkı ve çiş imgeleri müphemdir, tıpkı maddi bedensel alt bölgelere ait bütün imgeler gibi. Bu imgeler, aynı anda itibarsızlaştırır, yıkar, yeniden hayat verir ve yenilenirler; aynı anda kutsar ve alçaltırlar. O imgelerde ölüm ile ölüm sancıları, doğum ile doğum sancıları sımsıkı örülmüştür (Bahtin, 2005: 177).

Bahtin, Rabelais'nin dünya edebiyatında pazar meydanı hayatını en çok yansıtan yazar olduğunu ifade eder. Bahtin, gut ve zührevi hastalıkların maddi bedensel alt bölgelerle olan ilişkisini ortaya koyar. Zira bu hastalıklar aşırı yiyip içmekten ve de cinsel birleşmelerden kaynaklanmaktadır. Bir fıçı işkembe ifadesi grotesk edebiyatta popüler bir söylemdir. Bu imgenin neden önemli olduğundan Bahtin bahseder: Sindirim organları dışkılama ve dışkıyla ilişkilidir. Dahası karın sadece yiyip yutmaz, kendisi de tıpkı işkembe gibi yenir (Bahtin, 2005: 189). Rabelais eserlerini Kitab-1 Mukaddes'le karşılaştırır. Kilise gibi o da kitabına karşı çıkanları dinden çıkmakla suçlamaktadır. Rabelais'nin eserlerinde reklamların ve ilanların önemi büyüktür. İlacın reklamını yapan hekim imgesi önemlidir.

Şişirilmiş groteskin en önemli özelliği yiyeceklerin abartılı bir büyüklükte yapılmasıdır. Şişirilmiş grotesk imgeler göbek, ağız ve de fallusa gönderme yapmaktadır. Sövgüler ve beddualar konuşmanın gayrı resmi imgeleridir. Rabelais'nin eserlerinde sövgü sıkça karşımıza çıkmaktadır. Rabelais kendisine ve kitaplarına inanmayanlara beddua ve küfürle karşılık verir.

Fakat bu girişi bitirmeden önce, şayet kitap boyunca tek bir yalanım varsa, burada ruhumu ve bedenimi, karnımı ve bağırsaklarımı, yüz binlerce sepet dolusu gözü dönmüş ifrite sunmak istiyorum. Aynı şekilde şayet siz şu elinizdeki Vakayiname'de anlatacaklarıma düpedüz inanmazsanız Aziz Antonius sizi yılansı ateşiyle kavursun... Muhammed'in hastalığı sizi inim inim inletsin, fırıl fırıl döndürsün... tüm cerahatli iltihaplar, ülserler, frengi çıbanları size bulaşsın, sizi mahvetsin, parçalısın, bozsun, inek kılının yavaş yavaş kavrulması gibi kaba etinize girsin... ve Sodom ile Gomore gibi, kükürt ve ateş kuyusu sizi yutsun (Bahtin, 2005: 191). 
Karşılaştırma ve yüceltme sıfatları sıkça kullanılmaktadır: Şarap neşeli ve özgür hakikati zeytinyağı ise sofu bilgeliği ve acımayı temsil etmektedir. Şarap ve zeytin rind ve zahid ilişkisini hatırlatmaktadır. Genç Gargantua Paris ziyaretinde kalabalığın ilgisinden bunalır. Kalabalığı çişiyle sular. Aynı zamanda küfür ve beddua eder.

Sanırım bu serseriler beni karşılamalarına teşekkür etmemi, kendilerine bir armağan sunmamı istiyorlar. Hakları var. Ben biraz şarap ikram edeyim bari onlara, ama yalancıktan bir şarap. Sonra gözlerinin içi gülerek o güzel önlüğünü çözdü, maslahatını havaya kaldırıp öyle zorlu bir çiş yağmuruna tuttu ki onları, kadınları ve çocukları saymazsak, iki yüz altmış bin dört yüz on sekiz kişi boğuldu. Bu çiş sağanağından tabana kuvvet kaçıp kurtulanlar oldu, bunlar kan ter içinde öksüre aksıra, soluk soluğa üniversite yokuşunun en yukarısına varınca, kimi şakacıktan (par ris) sövüp saymaya başladılar: “Abaruabari! Tanrı korusun bizleri. Bir güzel yıkandık şakacıktan.”'Tanrının vebası, frengisi bulsun bunu!...olursa Tanrıyı inkar ederim!"(Bahtin, 2005: 217)

Bahtin, küfürlerin tematik izleklerini sorgular. Küfrün insan bedenini parçalara ayırdığını belirtir. Küfürlerin kutsal bedenin uzuvlarına edildiğinin altını çizer. Rabelais'nin eserlerinde beden uzuvlara ayrılır ve teşrih edilir.

Savaş makinelerinin ve silahlarının listelenmesi ve sokaklarda ilan edilişi sözlü bir geleneğe dayanmaktadır. XV ve XVI. yüzyılda yaygın bir gelenektir. Rabelais'nin eserlerinde seferberlik ilanları yapılır. Savaşlarda kullanılan silah tipleri duyurulur. Savaş sırasında ölen ve ödüle layık görülen askerlerin isimleri ilan edilir.

\section{Rabelais'de Popüler Şenlikli Biçimler ve İmgeler}

IV. Kitap'ta Pantagruel ile arkadaşları Mızıkçılar adlı bir adayı ziyaret ederler. Ada sakinleri geçimlerini dayak yiyerek kazanmaktadırlar. Rahip Jean da dövmek için kırmızı suratlı bir mızıkçı seçer:

Rahip Jean, sopasını şöyle bir savurdu, Kırmızı Suratın karnına, sırtına, kafasına, bacaklarına öyle bir hırsla vurdu ki, yoğrulmuş hamur gibi yere düştüğünde, Mızıkçı ölecek diye korktum. (IV. Kitap, XVI. Bölüm)Gördüğünüz gibi bedenin anatomik kısımlarının listelenmesi ihmal edilmemiş. Rabelais şöyle devam eder: "Sonra ona yirmi lirasını verdi. Sefil adam, bir kral -ya da belki iki kral gibi mutlu, ayağa kalktı. (Bahtin, 2005: 224)

Bahtin bir kral ve iki kral imgesinin ödülünü alan mızıkçının mutluluğunu yansıttığını ifade eder. Mızıkçının kırmızı suratının ise ölümü temsil ettiğini belirtir. Sövgü ölümdür; eskiden genç olanın ihtiyar haline gelişidir; yaşayan bedenin cesede dönüşmesidir. $O$, tarihsel bir ölüm yaşaması gerekeni yansıtan "komedinin aynası”dır. Ancak bu sistemde ölümün ardından, yeniden hayat bulma, yeni bir yıl, taptaze bir gençlik ve bir kez daha 
ilkbahar gelir; bunlar, bir dünyanın, her biri kendine ait bir bedene sahip olan iki veçhesidir (Bahtin, 2005: 225).

Tacı elinden alarak sövme imgesi Rabelais'nin eserlerinde önemli bir yere sahiptir. Gargantua'da Picrochole ve Pantagruel'de Anarchus adlı kralların taçları elinden alınır:

Kral Picrochole yenilgisi üzerine kaçar; yolda ayağı kayıp düştüğü için atına sinirlenir ve onu öldürür. Yolculuğuna devam etmek için yakınlardaki bir değirmenden eşek çalmaya çalışır; ancak değirmenciye yakalanır. Değirmenci onu döver, üzerindeki kral kıyafetlerini alır, bir iş kıyafeti giydirir. Daha sonra işten atılan kral Lyon'da sıradan bir işçi olarak çalışır. (Bahtin, 2005: 226)

Kral Anarchus'un tacının alınması da benzer karnavalesk ruhla resmedilmiştir. Pantagruel, Anarchus'u yendikten sonra onu Panurge'e teslim eder; o da ilk önce eski krala tuhaf bir soytarı kıyafeti giydirir, sonra onu kuzukulağı satmaya gönderir. Bu hiyerarşinin en alt katıdır. Dayak atmayı da unutmaz. Evet, Panurge onu doğrudan dövmez ama onu ihtiyar aksi bir acuzeyle evlendirir. Kadın eski krala söver, onu döver durur. Burada bir kez daha eski karnavalesk geleneğe sıkı sıkıya bağlı kalınmıştır. (Bahtin, 2005: 226)

Davul imgesi ve düğündeki tokatlamalar cinsel edime gönderme yapar. Bahtin, çınlayan çan imgesinin karnavalların popüler imgelerinden biri olduğunu dile getirir. Gargantua "Notre DameKatedrali" nin çanlarını çalar. Katedralin çanlarını çalıp sonrasında bir kısrağa takmak tipik bir karnavalesk küçültme imgesidir. Karnaval ruhu bağbozumu ve hayvan kesimi gibi bayramlarda ortaya çıar. Bu karnaval ruhunun izleri Rabelais'nin eserlerinde görülmektedir.

Gargantua'nın doğumu hayvan kesimi bayramında gerçekleşir. Gargantua'nın doğumundan sonra şölen düzenlenir. Şölen ruhu tün canlılığıyla yaşanır. Bolluk ve refah bir atmosfer içerisinde şölen yapılır.

Pazar meydanında oyunların önemli bir yeri vardır. İskambil oyunları, çeşitli sporlar, fal okumalar, dilek tutmalar, tahminler Rabelais'nin eserlerinde önemli bir rol oynar. Gargantua ve Pantagruel'in eğitiminde oyunlar önemli bir yer teşkil eder. Oyunlar zaman ve gelecekle bağlantılıdır. Zar ve iskambil kâğıtları fal bakmak için kullanılır.

Kehanetin astrolojik tahminlerin parodisini yapan ilk bölümünde Rabelais ilk başta bunları demokratikleştirir. Yıldızların sadece krallar, papalar, asiller ile resmi dünyanın büyük olayları için olduğuna inanmanın en büyük çllgınlık olduğunu düşünür. Astroloji, altsınıfların hayatları ve kaderleriyle de ilgilenmelidir. Bu bir anlamda, yıldızların tacının elinden alınması, üzerinden saraylı kılıkların çıkarılmasıdır. (Bahtin, 2005: 262)

III. Kitap'ta Panurge kaderini sınar. Evlenmek istemektedir; ama aldatılmaktan onun tabiriyle boynuzlanmaktan korkmaktadır. Gelecekte bu akıbeti yaşayıp yaşamayacağını merak eder. 
Kadınların iç organları tüketilemez ve asla tatmin edilemez. Kadın yaşlı olan her şeye düşmandır. Panurge'ün tacı kaçınılmaz olarak elinden alınacak, kendisi dövülecek daha kötüsü öldürülecektir. (Bahtin, 2005: 270)

\section{Rabelais'de Şölen İmge Dokusu}

Bahtin, yiyip içme, yalayıp yutma gibi şölen imgelerinin Rabelais'nin eserlerinde popüler şenlik ruhuyla bağlantılı olduğunu ifade eder. Yeme içmenin grotesk bedenin önemli simgelerinden biri olduğunu, yemeğin savaşa ve işe son verdiğini dile getirir. Yemek zafer tacı olur. Şölen imgeleri Rabelais'nin eserlerinde önemli bir yere sahiptir:

Kocaman açılmış ağız, yalayıp yutma temasıyla beraber Pantagruel'in başlıca temalarından biridir ve beden ile yemek imgeleri arasında eşikte yer alır. Başka bir imgede Pantagruel'in annesinin, doğum sancları arasındaki açık rahmidir; o rahimden, tuzlanmış yemekle dolu bir dizi yük arabası çıkar. Bu örneklerde, yemek imgelerinin, beden ve hasıl etmeyle (doğurganlık, büyüme, doğumla) ilgili imgelerle ne kadar yakından bağlantılı olduğunu görüyoruz (Bahtin, 2005: 308).

Şölenler Gargantua'da da önemli bir yere sahiptir: Kitap bir hayvan kesimi şenliğiyle başlar. Yeme içme imgeleri, Gargantua'nın eğitiminde ciddi bir yer tutar. Gargantua Picrochole Savaşı'nın başlangıcında eve geldiğinde bir şölen düzenler; sofradaki tüm yemeklerin, şölende oynanan bütün oyunların ayrıntılı bir listesi verilir (Bahtin, 2005: 309).

III. Kitap'ta şölen imgelerine bazı epizotlarda yer verildiğini; ancak azaldığını ifade eder. Bahtin, IV. Kitap'ta sosis savaşındaki karnaval sahneleri ve Mideye Tapanlar epizotunda dünya yemek literatüründen alınan uzun listelere yer verildiğini belirtir.

Şenliklerde gelecek güzel günlerden bahsedildiğini, şölen sofralarında yapılan sohbetlerin geçmiş ve şimdi prangasından kurtardığını ifade eder. Bahtin, burjuva edebiyatındaki yeme içme imgelerinin bencil bireyin memnuniyetini temsil ettiğini dile getirir. Bu imgelerin pazar meydanı ruhundan uzaklaştığını ve mahrem salonlara kapatıldığını vurgular.

\section{Bedenin Grotesk İmgesi ve Bunun Kökenleri}

Abartı, şişirmecilik ve aşırıya kaçma grotesk biçimin temel özellikleridir. Bahtin, Alman akademisyen G. Schneegans'ın grotesk tarihini ve kuraminı tutarlı ve belgelere dayandırarak incelediğini ifade eder. Akademisyen çalışmaları 1894'te Grotesk Yerginin Tarihi adı altında yayımlanır. Ancak akademisyenin groteskin müphemliğini görmezden geldiğini ifade eder. Schneegans Rabeais'nin eserlerinde yer alan grotesk imgelerden örnekler verir. Rahip Jean manastırın çan kulesinin gölgesinde bile meyve yetiştiğini söyler: 
Rahip Jean manastır çan kulesinin gölgesinin bile bir kadını daha doğurgan yapacağı yolunda bir iddiada bulunur. Bu imge bizi groteskin mantığına götürür. Bu, manastırdaki "ahlak bozukluğunun" bir abartısı değildir sadece. Nesne kendi sınırlarını ihlal eder, kendi olmayı bırakır. Beden ile dünya arasındaki sınırlar silinir, ikisinin birbiriyle ve çevresindeki başka nesnelerle kaynaşmasına giden yol açılır. Çan kulesinin (bir kule) fallusa ait yaygın grotesk simge olduğunu hatırlayalım. (Bahtin , 2005: 340)

Bahtin, bu grotesk imgelere dair önemli bir tespit yapar: Bu imgelerin kudretli maddi bedensel öğesi inancıyla, azizleriyle, kutsal yadigârlarıyla, manastırlarıyla, yalancı çileciğiyle, ölüm korkusuyla, kehanetleriyle tüm bir ortaçağ ideolojisine ve düzenine ait dünyanın tacını elinden alır, onu yeniler. Silip süpürülecek olan bu dünyada hacılar ufacık, acınası figürlerden başka bir şey değildir; salatanın içinde fark edilmeyen yutulabilir. İdrarın içinde neredeyse boğulup gidebilirler. Bir çan kulesi kadar uzun olan manastır fallusu, Gargantua'nın çişinin seli ve her şeyi yutan muazzam gırtlağı (Bahtin, 2005: 342).

$\mathrm{Bu}$ imge ile manastırın ve onun sahte çileci idealinin tacı elinden alınır. Yukarıyı yani cennete işaret eden kule kadınları hamile bırakan fallusa dönüşmüştür. Alman akademisyenin Rabelais'nin eserlerinden seçtiği bir başka grotesk imge ise Panurge'ün kadınların cinsel organlarından bir duvar inşa etme önerisidir:

Panurge'ün ilk ve en önemli zırhın cinsel organları koruyan koruma olduğunu anlatan uzun nutkunu görürüz. Bir erkeğin kellesi uçurulduğunda yeryüzünden silinen sadece o adam olduğunu söyler; hâlbuki cinsel organını kaybederse tüm insan ırkı yok olacaktır. (Bahtin, 2005: 344)

Panurge insanoğlunun çıplak doğmasını doğa karşısında barış dolu bir düzene davet edilmesine bağlar. Grotesk gerçekçilikte ön önemli imgeler burun, ağız, kafa, kulak ve pörtleyen gözlerdir. François Rabelais Pantagruel'i 1532' de patlak veren kuraklık döneminde kaleme almıştır. O zamanlarda sıcaklardan dolayı insanların ağızları açık bir şekilde dolaştıkları rivayet edilir. Pantagruel'in doğumu sırasında gerçekleşen kuraklık romanda şu şekilde anlatılır:

hayvanlar, ağızları hayretle ardına kadar açık vaziyette tarlalarda ölü bulunuyorlardı. İnsanlara gelince durumları hazindi. Onları, altı saattir av peşinde koşan tazılar gibi dilleri sarkar şekilde görmüş olmalısınız. Kendini kuyulara atanların sayısı hiç de az değildi. Başkaları gölgesinden yararlanmak için bir ineğin göbeğinin altına uzanmıştı... Tanrı bilir kutsal suları korumak son derece zordu... kavrulmuş, mutsuz, biçareler, kutsal suyu dağıtan rahibin peşinde dolaşıyorlardı, küçücük bir damla yakararak... Ah! Serin şarap mahzenlerinin tıka basa olduğu o y1l neydi öyle, insanlar ne kadar mutluydu! (Bahtin, 2005: 359-360)

Bahtin, kuyu, ineğin göbeği ve mahzen imgelerinin açıkağız imgesine işaret ettiğini vurgular. Pantagruel midesinden rahatsızdır. Hastalığı sırasında çok fazla işediği için 
çişinden Fransa ve İtalya'nın çeşitli yörelerinde şifalı kaplıcalar oluşmuştur. Epizotta Pantagruel'i hastalıktan kurtarmak için midesine iniş hikâyesi anlatılır:

Kazma, kürek, sepetlerle kuşanmış adamlar bakır bir kürenin içine doldurulurlar, Pantagruel bunu hap gibi yutar.(Yutma imgesine dikkat edin) Mideye indiklerinde ziyaretçiler küreklerinden çıkar, etrafı temizlerler. Pantagruel'in ağzı gibi midesi de devasa neredeyse kozmik boyutlardadır (Bahtin, 2005: 368). Ardına kadar açıkağız ve yiyip yutma Rabelais'nin imgeler dünyasında önem arz etmektedir.

\section{Maddi Bedensel Alt Bölgelere Ait İmgeler}

Rabelais'nin dünyasında her yer birbirine eşittir. Bu alg1 yazara evrenin merkezini gökten indirip yeraltına indirme fırsatı sunar. Küçültme, grotesk gerçekçiliğin temel sanat ilkesidir; kutsal ve yüceltilmiş olan her şey maddi bedensel alt bölgeler düzeyinde yeniden ele alınır ve oraya ait imgelerle birleştirilir, karıştırılır (Bahtin, 2005: 402).

Gargantua'nın kıç silgeçlerini anlattığı epizot dikkat çekicidir. Gargantua babasına pek çok denemesinden sonra keşfettiği kıçs ilgecini anlatır. Bir nesnenin kıç silgecine dönüşmesi bir küçültmedir. Tacı elinden alınır: Kıç silgeçlerinin seçimi salt keyfi nedenlerle yapılmamıştır. İlk beş nesneye bakalım: Maske, kukuleta, boyun atkısı, kulaklıklar, külah. Bunlar yüze ve kafaya takılan şeylerdir, yani bedenin üst kısmında kullanılırlar. Kıç silgeci olarak kullanımları bedenin üst bölgelerinin alta aktarılmasıdır. (Bahtin, 2005: 403-404)

Salatalar, baharatlar, şifalı otlar, sebze yaprakları, sapları. Bunlar arasında yenmek ve yutulmak içindir. Yukarının yerine aşağının, yüzün yerine kullanılmaları bedenin üst bölgelerinin alta aktarılmasıdır. (Bahtin, 2005: 406)

Epistemon'un dirilişi ve yer altı dünyasında gördükleri epizot dikkat çekicidir: Epistemon söze başladı. İblisleri görmüş, onlarla söyleşmiş, Lucifer'le muhabbet etmiş, cehennemde ve Cennetin Bahçelerinde çılgınca eğlenmiş. İblisler, diyor, öyle mükemmel dostlar, öyle neşeli yarenlerniş ki, Panurge onu çabuk geri çağırdı diye sitem etmiş. “Onları öyle kalabalık görmek hoşuma gitti." “Nasıl yani?” Diye sordu Pantagruel.

“Öyle düşündüğün gibi kötü davranılmıyor onlara,” diye açıkladı Epistemon. "Bütün mesele şu: İçinde bundukları durum tuhaf bir şekilde değişmiş.Mesela Büyük İskender'i gördüm...Eski çorapları yamayarak kıt kanaat geçiniyor. Kserkses hardal satıyor, Romulus tuzcu olmuş, Romalı kanun yapıcısı Numa Pompilusnalbant, Tarquinhamal, Galba'nın halefi Piso aptal bir köylü... (Bahtin, 2005: 415) Görüldüğü gibi en üst sınıfı temsil edenlerin taçları ellerinden alınmıştır. Alt sınıfı temsil edenler ise taçlandırılmıştır:

“Cehennemin kanunu budur," diye açıkladı Epistemon yeryüzünün büyük lordları, leydileri aşağıda en şerefsiz, en sefil rizikolu geçim yolları için mücadele etmeye mahkum 
edilirler. Öte yandan filozoflar gibi bu gezegende muhtaç bir hayat sürmüş olan kimseler, infernoda azametli lordlar olurlar.

Diogenes'igördüm... lükslerin en muhteşemi içindeydi, keyfini çıkarıyordu. Kat kat, mor bir kaftan giymişti, sağ elinde de bir kral asası vardı. Büyük İskender, Diogenes'in pantolonunun kalça yerlerini doğru dürüst yamalayamayınca, Diogenes, bir güzel sövüp saydı; eski imparator, karşısında tir tir titriyordu. Bu beceriksizliğinden dolayı onu bir güzel dövmeyi de unutmadı. (Bahtin, 2005: 416)

Cehennem bir şöleni neşeli bir karnaval imgesini temsil etmektedir. Resmi ortaçağ zihniyetinde yer altı dünyası korku ve kasvetin merkezidir. Hıristiyan cehennemi dünyayı değersizleştirip insanı ondan uzaklaştırdıysa, karnavalesk cehennem dünyayı ve onun içinde ölümle doğumun yüz yüze geldiği ve hayatın tomurcuklandığı bir rahim olarak görülen alt bölgelerini onayladı. Maddi bedensel alt bölgelere ait imgelerin karnavallaştırılmış yer altı dünyasında hâkim oluşunun nedeni budur (Bahtin, 2005: 427).

Rabelais'nin eserlerinde ikili beden imgesi önemli bir yer teşkil eder. İhtiyarlığın gençliğin içinde yeniden yeşerdiğini ifade eder. Sözel absürtlük biçimleri Ortaçağ' da yaygın kullanımlardır. Bu deyişler anlam bağlamından koparılmıştır:

Gargantua her zaman özdeyişe rağmen kafasına göre hareket eder, yani özdeyişin tavsiyesinin tam tersini yapar. Örneğin ağzına çiğneyebileceğinden büyük lokmalar alır, dereyi görmeden paçayı sıvar, demiri soğukken döver. Bu oyunun sonunda Genç Gargantuaimgesi, hareketleri akla aykırı olan aklıselimin bütün normlarına karşı gelen folklorik soytarı ruhuyla kurulur. (Bahtin, 2005: 458)

\section{Rabelais'nin İmgeleri ve Dönemi}

Bahtin, Rabelais'nin çağdaşlarının hatıralarından yararlanarak altı ay süren kuraklık ve kıtlığın Pantagruel'in yazıldığı 1532 yılında yaşandığını ifade eder. Pantagruel'in Rabelais'nin aşina olduğu bölgelerde seyahat etiğini dile getirir. Pantagruel, Rabelais'nin gördüğü yerleri görür ve de onun arkadaşlarıyla tanışır. Bahtin'in diğer önemli tespiti ise Gargantua'nın doğum günüdür. Gargantua 4 Şubat hayvan kesimi şenliğinde doğmuştur. Bu yer ve tarihin Rabelais'nin doğum yeri ve tarihi olduğunu ifade eder.

Bahtin, Rabelais'nin eserlerinin dönemin siyasi olayları ile yakından ilişkisi olduğunu dile getirir. Gargantua'da V.Charles'a karşı verilen mücadele anlatılır. Bahtin, Rabelais'nin tıp, doğal bilimler, hukuk, mimarlık, askerlik, denizcilik, yeme içme sanatı, kuşçuluk, oyunlar, spor, para ve madalya ilmine dair tecrübelerini eserlerinde yansıttığını ifade eder. Bahtin, Rabelais'nin eserlerinde Gargantua, Gargamelle, Pantagruel, Grandgouiser gibi takma isimler kullandığını söyler. Rabelais'nin bu dört ismi gelenekten devraldığını belirtir. 
Grandgouise büyük gırtlak, Gargamelleise gırtlak anlamına gelir. Bu isimlerin yiyip içme imgelerini temsil ettiğini ifade eder.

Antik ve ortaçağ edebiyatında sayıların simgesel, metafiziksel ve mistik kullanımları olduğunu ifade eder. O çağlarda sayıların kutsal olarak görüldüğünü belirtir. Ancak Rabelais'nin sayıları kutsal anlamlarından kurtarır. Sayıların tacını alır. Onları somutlaştırır.

Grotesk sayılar şaşırtıcı, abartıcı ve komik bir etki yaratmaktadır. Rabelais'nin eserlerinde yer alan sayılar kararsız, müphem ve tamamlanmamıştır: Gargantua üç ay, yedi gün, on üç saat, kırk yedi dakika boyunca işer ve Rhone Nehri'ni ve yedi yüz gemiyi doğurur. (Bahtin, 2005: 177)

Mihail Bahtin, François Rabelais'nin eserlerini daha çok içerik analizi ile incelemektedir. Bahtin'i yapısalcı bir okumayla incelemek çok verimli olmayacaktır. Art zamanlı bir okuma yapmaya elverişlidir. 